\title{
Occurrence of Cowpea aphid-borne mosaic virus in Peanut in Brazil
}

G. Pio-Ribeiro, Universidade Federal Rural de Pernambuco, Dois Irmãos, Recife, PE - CEP: 52 171-900, Brazil; S. S. Pappu, Department of Entomology, and H. R. Pappu, Department of Plant Pathology, University of Georgia, Coastal Plain Experiment Station, Tifton 31793; G. P. Andrade, Universidade Federal Rural de Pernambuco, Dois Irmãos, Recife, PE - CEP: 52 171-900, Brazil; and D. V. R. Reddy, International Crops Research Institute for the Semi-Arid Tropics, Patancheru, Andhra Pradesh 502 324, India

\section{ABSTRACT}

Pio-Ribeiro, G., Pappu, S. S., Pappu, H. R., Andrade, G. P., and Reddy, D. V. R. 2000. Occurrence of Cowpea aphid-borne mosaic virus in peanut in Brazil. Plant Dis. 84:760-766.

Surveys of peanut crops in northeastern Brazil since 1995 showed the occurrence of a hitherto unreported virus disease. Characteristic leaf symptoms were ring spots and blotches. The virus was seed transmitted in peanut (1/610) and cowpea (47/796). Local and systemic symptoms were observed in cowpea (cv. TVu 3433) known to be susceptible to most Cowpea aphid-borne mosaic virus (CABMV) isolates. The virus was transmitted by aphids Toxoptera citricidus and Aphis gossypii. Using degenerate primers, the $3^{\prime}$ terminal region of the viral genome was cloned and sequenced. Sequence analyses of the coat protein and the $3^{\prime}$ untranslated region indicated that the potyvirus was most closely related to CABMV isolates from South Africa, Zimbabwe, and the United States. On the basis of genome analysis, the virus was identified as CABMV. The natural occurrence of CABMV on peanut has so far not been reported. The significance of this finding especially for germ plasm exchange is discussed.

Additional keywords: aphid transmission, coat protein gene, seed-borne infection, sequence relationships

Peanut or groundnut (Arachis hypogaea L.) is a legume crop grown extensively in many tropical and subtropical areas as a source of oil and dietary protein. In the northeastern region of Brazil, it is grown as a sole crop or intercropped with other legumes.

According to Sreenivasulu et al. (22), 23 taxonomically characterized viruses belonging to 13 genera have been found to infect peanut under natural conditions. Some of them are economically important (17). Thirty-nine other viruses of 16 genera can be transmitted to peanut under laboratory conditions (22). Two naturally occurring economically important potyviruses in peanut are Peanut mottle virus (PeMoV) and Peanut stripe virus (PStV). They have been reported to occur in the majority of peanut-growing countries. Several potyviruses that are restricted in their geographic distribution have also been reported (5).

Systematic surveys have not been undertaken in Brazil to determine the distribution of various viruses occurring natu-

Corresponding author: G. Pio-Ribeiro

E-mail: pio@elogica.com.br

The sequence reported here is available from GenBank under accession number AF241233.

Accepted for publication 20 March 2000.

Publication no. D-2000-0427-01R

(C) 2000 The American Phytopathological Society rally in peanut. Brazil is one of the centers of origin for peanut and is often explored for the collection of various wild Arachis species. Therefore, data on the occurrence of various viruses and the availability of methods for their diagnosis are crucial for germ plasm conservation and movement. In annual surveys from 1995 to 1998 conducted in the peanut growing areas of the northeastern region of Brazil, plants showing ring spots and blotches were noticed. Preliminary studies indicated that the symptoms were caused by a potyvirus. The purpose of this work was to investigate the natural occurrence of this virus in successive years and its characterization by biological, serological, and molecular studies. Preliminary results have been published (16).

\section{MATERIALS AND METHODS}

Collection of material. Surveys were undertaken during the growing season, May to September, in the northeastern region of Brazil. In 1995, surveys were restricted to Paraíba, the major peanut producing state, where 36 farmers' fields were surveyed. During 1996, 1997, and 1998, more than 100 peanut fields were surveyed in Paraíba and in two other northeastern states, Pernambuco and Bahia (Fig. 1). Peanut plants showing characteristic ring spots and blotches were collected.

In 1996 and 1998, in February and March, respectively, several peanut fields in São Paulo, located in southeastern Brazil, were also surveyed (Fig. 1).
The majority of farmers in northeastern Brazil intercrop peanut with cowpea (Vigna unguiculata (L.) Walp. subsp. unguiculata), bean (Phaseolus vulgaris L.), and lima bean (P. lunatus L.). Leaf samples from intercropped legumes showing symptoms were also collected.

Maintenance of virus isolates. Since the virus consistently produced local lesions on Chenopodium amaranticolor Coste \& Reyn., five single-lesion isolates, obtained after four successive single-lesion transfers, were maintained individually in peanut cv. BR-1 or cowpea cv. Clay. All single-lesion isolates were stored at $4^{\circ} \mathrm{C}$ in dried leaf tissue. This tissue was used at regular intervals to maintain the virus isolate and to ensure that individual isolates were not cross contaminated. Leaf samples collected from intercropped legumes that gave a positive reaction with PStV antiserum were mechanically inoculated onto peanut cv. BR-1.

Transmission. To determine seed transmission, 650 seeds from field infected peanut plants (cv. BR-1) and 810 seeds from field infected cowpea (cv. Sempre Verde) were analyzed. For peanut, a nondestructive test based on enzymelinked immunosorbent assay (ELISA) described by Bharathan et al. (3) and Demski and Warwick (7) was used to test for the presence of virus. All ELISA-tested seed were raised under glasshouse conditions, and 1-month-old seedlings were scored by visual symptoms and by direct antigen coated-ELISA (DAC-ELISA) using PStV antiserum.

For aphid transmission studies, nonviruliferous, apterous aphids Aphis gossypii Glov. and Toxoptera citricidus Kirk. were used. After $1 \mathrm{~h}$ of starving, the insects were allowed an acquisition access of $3 \mathrm{~min}$ on young, diseased peanut leaves. Groups of 10 aphids were then transferred to individual healthy peanut plants. After 1 day, the insects were killed with an insecticide. Aphid transmission was tested from peanut to cowpea, peanut, and soybeans (Glycine $\max$ (L.) Merr.). Virus transmission was tested with both aphid species from peanut to peanut and from peanut to cowpea and with $T$. citricidus from peanut to soybean.

Serological tests. Leaf tissue from plants inoculated with isolates that produced typical ring spots and blotches sur- 
rounded by a chlorotic halo were tested by DAC-ELISA as described by Hobbs et al. (9). Antisera specific for potyviruses $\mathrm{PeMoV}$ and PStV (from International Crops Research Institute for Semi Arid Tropics), Bean common mosaic virus (BCMV), Maize dwarf mosaic virus (MDMV), Pea seed-borne mosaic virus (PSbMV), Soybean mosaic virus (SbMV), and Sugarcane mosaic virus (SCMV) (from J. W. Demski) were used.

Virus purification. The virus purification procedure used was similar to that reported (6) for PStV with the following modifications. Peanut leaflets were homogenized ( $1 \mathrm{gm}$ per $4 \mathrm{ml}$ ) with cold 0.1 $\mathrm{M}$ phosphate buffer, $\mathrm{pH}$ 8.0, containing $0.01 \mathrm{M}$ sodium diethyldithiocarbamate and 1\% 2-mercaptoethanol. Precipitates following polyethylene glycol treatment were resuspended in $0.01 \mathrm{M}$ boratephosphate (BP) buffer, $\mathrm{pH} 8.3$, containing $0.5 \%$ Triton $\mathrm{X}-100$. Virion preparations following high-speed centrifugation were also suspended in BP containing Triton X-100.

Template preparation for amplification. The template was prepared by immunocapture (IC) of the virions. Thin-walled microfuge tubes were treated for $15 \mathrm{~min}$ each in $0.1 \mathrm{~N}$ hydrochloric acid and $4 \mathrm{~N}$ sodium hydroxide and rinsed with PBST (0.02 $\mathrm{M}$ phosphate, $0.15 \mathrm{M}$ saline, $0.05 \%$ Tween 20, $\mathrm{pH} 7.5$ ). Tubes were finally washed with $95 \%$ ethanol for $15 \mathrm{~min}$ before they were air-dried at room temperature (10). Tubes were then coated with 100 $\mu \mathrm{l}$ of monoclonal antibody PTY1 (courtesy of Ramon Jordan, USDA-ARS, Beltsville, MD) diluted 1:200 in carbonate coating buffer (0.05 M carbonate, $\mathrm{pH}$ 9.6) and incubated overnight at $4^{\circ} \mathrm{C}$. Tubes were washed three times with sterile distilled water and either used immediately or airdried and stored at $4{ }^{\circ} \mathrm{C}$ until use.

Purified virus was resuspended in a solution of $50 \mathrm{mM}$ Tris $\mathrm{HCl}$ and $1 \mathrm{mM}$ EDTA, $\mathrm{pH} 8.0$, and $100 \mu \mathrm{l}$ was added to the tube containing the antibody. Tubes were incubated at room temperature $\left(22^{\circ} \mathrm{C}\right)$ for 2 to $3 \mathrm{~h}$ and washed four times with sterile distilled water. To destabilize antibody-bound virus particles, $47 \mu \mathrm{l}$ of sterile distilled water was added to each tube, and the tubes were subjected to two cycles of freezing $\left(-80^{\circ} \mathrm{C}\right.$ for $\left.10 \mathrm{~min}\right)$ and thawing by heating $\left(70^{\circ} \mathrm{C}\right.$ for $\left.5 \mathrm{~min}\right)$. Tubes were then transferred to wet ice for reverse transcription and polymerase chain reaction (RT-PCR). Sap extracts from noninfected tissues served as a control.

RT-PCR amplification. The RT-PCR reaction was performed as a one-tube, single-buffer procedure described previously (10) with minor modifications. A set of degenerate primers that amplify the $3^{\prime}$ terminal region, including a part of the NIb gene, the complete coat protein (CP) gene, and the $3^{\prime}$ untranslated region (UTR), were described previously (13-15). The PCR reaction $(100 \mu \mathrm{l})$ contained $500 \mathrm{ng}$ of the upstream genome sense primer (5'-ATG $\mathrm{AT}(\mathrm{A} / \mathrm{C} / \mathrm{T}) \mathrm{GA}(\mathrm{A} / \mathrm{G})(\mathrm{G} / \mathrm{T}) \mathrm{CN}$ TGG GG3'), $300 \mathrm{ng}$ of the downstream genome anti-sense primer (a mixture of equal amounts of the three primers $\mathrm{T}_{21} \mathrm{~A}, \mathrm{~T}_{21} \mathrm{C}$, and $\left.\mathrm{T}_{21} \mathrm{G}\right), 16$ to 20 units of RNasin (Promega Corporation, Madison, WI), 16 units of AMV reverse transcriptase (Promega), 2.5 units of Taq Polymerase (Qiagen Inc., Chatsworth, CA), 1× PCR buffer (Qiagen), $10 \mathrm{mM}$ Dithiothreitol, 1× $\mathrm{Q}$ solution (Qiagen), and $200 \mu \mathrm{M}$ of each of the dNTPs (Amersham Lifescience Inc., Arlington Heights, IL). For IC-RT-PCR, the PCR mix $(53 \mu \mathrm{l})$ containing the above components was added to the tube containing the template $(47 \mu \mathrm{l})$ that was previously subjected to freeze-thaw cycles, resulting in a final reaction volume of $100 \mu \mathrm{l}$. Amplification was performed in an automated thermal cycler (Model GeneAmp 2400, Perkin-Elmer Corp., Norwalk, CT) programmed for 1 cycle of $42^{\circ} \mathrm{C}$ for 45 min for cDNA synthesis, and 40 cycles of amplification with the following parameters: 1 min of denaturation at $90^{\circ} \mathrm{C}, 2 \mathrm{~min}$ of annealing at $42^{\circ} \mathrm{C}$, and 4 min of extension at $72^{\circ} \mathrm{C}$ followed by 1 cycle of final extension for $60 \mathrm{~min}$ at $72^{\circ} \mathrm{C}$.

Analysis of PCR products. Following PCR, reaction products $(10 \mu \mathrm{l})$ were analyzed by $0.8 \%$ agarose gel electrophoresis in TBE buffer containing ethidium bro- mide (19). DNA was visualized and photographed using a UV transilluminator (Fisher Scientific Co., Pittsburgh, PA) and Gel Print 2000i gel documentation apparatus (BioPhotonics Corporation, Ann Arbor, MI). Lambda DNA digested with HindIII was used as a size standard.

cDNA cloning and sequencing of the $3^{\prime}$ terminal region. PCR-amplified DNA was fractionated on $0.8 \%$ low melting point agarose gel (Bethesda Research Laboratories, Gaithersburg, MD). The approximately $1.2-\mathrm{kb}$ band was excised under UV light, extracted with phenol:chloroform, and precipitated with 0.1 volume of $3 \mathrm{M}$ sodium acetate, $\mathrm{pH}$ 5.2, and 2 volumes of ethanol. The nucleic acid was pelleted in a refrigerated centrifuge at $11,500 \times g$ for $15 \mathrm{~min}$. The resulting pellet was then washed with $70 \%$ ethanol followed by drying in a Savant SpeedVac. The PCR product was ligated into pGEM-T vector (Promega), and competent Escherichia coli (strain DH5a) was transformed by following standard molecular biology procedures (19). Recombinant clones were identified by restriction endonuclease digestion, and selected clones were sequenced at the DNA Sequencing Center, University of Florida, Gainesville.

Sequence analyses. Sequence data were initially compiled using Seqaid Version 3.6 (18). Multiple alignments were done using

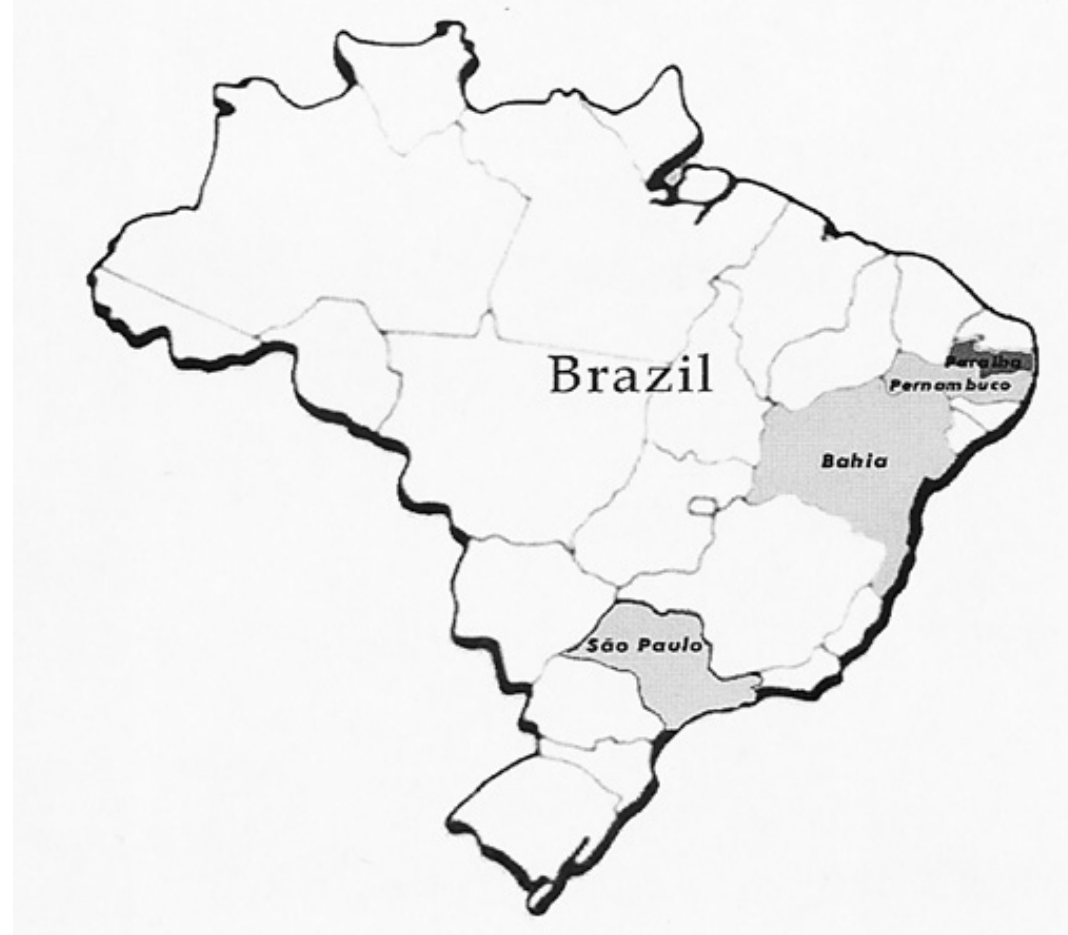

Fig. 1. Outline of Brazil indicating the area surveyed (shaded) to determine the incidence of potyviruses in peanut and cowpea. Dark shading indicates occurrence of the potyvirus characterized in this study. 
CLUSTAL W (25), and maximum likelihood analysis was done using the PUZZLE program (23) provided within the phylogenetic analysis program package PAUP (24). 1,000 puzzling steps and visualized using TreeView (12). Sequence analyses and sequence comparisons with those available in GenBank (2) were performed using the programs of the Genetics Computer Group (8). The BLAST program (1) was used to identify related sequences available from the GenBank database. Unrooted trees were constructed using

\section{RESULTS}

Survey. Four of 36 farmer fields surveyed in 1995 in the states of Paraíba contained peanut plants with leaf symptoms of ring spots and blotches. In the surveys conducted in 1996, 1997, and 1998 in the same area of Paraíba, 13 peanut fields intercropped with cowpea and two with peanut as a sole crop had plants with these disease symptoms. Disease incidence among fields was highly variable. In those with peanut as sole crop, 15 to 20 symptomatic plants were found scattered in each

Table 1. Reaction of diagnostic species to mechanical inoculation with a peanut isolate of Cowpea aphid-borne mosaic virus

\begin{tabular}{|c|c|c|}
\hline \multirow[b]{2}{*}{ Test host (family/species/cultivar) } & \multicolumn{2}{|c|}{ Symptoms $^{\mathrm{a}}$} \\
\hline & Local & Systemic \\
\hline \multicolumn{3}{|l|}{ Chenopodiaceae } \\
\hline Chenopodium amaranticolor & CL & $-^{\mathrm{b}}$ \\
\hline C. murale & - & - \\
\hline \multicolumn{3}{|l|}{ Cucurbitaceae } \\
\hline Cucumis sativus cv. Marketer & - & - \\
\hline \multicolumn{3}{|l|}{ Leguminoseae } \\
\hline Arachis hypogaea cv. BR-1 & SI & $\mathrm{Bl}, \mathrm{CRS}$ \\
\hline cv. Florunner & SI & $\mathrm{B} 1, \mathrm{CRS}, \mathrm{LD}, \mathrm{Mt}$ \\
\hline cv. IAC-22 & SI & B1,CRS,LD \\
\hline cv. Havana & SI & B1,CRS \\
\hline cv. BRS $151 \mathrm{~L}-7$ & SI & CRS,LD,B1 \\
\hline cv. Tatu & SI & CRS,LD,B1 \\
\hline Arachis sp. ${ }^{\mathrm{c}}$ & - & - \\
\hline Wild Arachis sp. ${ }^{\mathrm{d}}$ & SI & Mt \\
\hline Glycine $\max$ cv. Vale do Rio Doce & SI & Mt \\
\hline Phaseolus vulgaris cv. IPA-7419 & NL & - \\
\hline \multicolumn{3}{|l|}{ Vigna unguiculata subsp. unguiculata } \\
\hline cv. Clay & SI & Mo \\
\hline cv. Carrapicho & SI & Mo \\
\hline cv. Sempre Verde & SI & Mo \\
\hline cv. Pitiúba & SI & Mo \\
\hline cv. TVu 3433 & $\mathrm{NL}, \mathrm{VN}$ & Mo,SN,PD \\
\hline \multicolumn{3}{|l|}{ Solanaceae } \\
\hline Datura metel & - & - \\
\hline Nicotiana benthamiana & SI & Mo \\
\hline N. debneyii & - & - \\
\hline N. glutinosa & - & - \\
\hline
\end{tabular}

${ }^{\mathrm{a}} \mathrm{Bl}=$ blotches; $\mathrm{CRS}=$ chlorotic ring spots; $\mathrm{CL}=$ chlorotic lesions; $\mathrm{NL}=$ necrotic lesions; $\mathrm{LD}=$ leaf distortion; $\mathrm{Mo}=$ mosaic $; \mathrm{Mt}=$ mottle; $\mathrm{PD}=$ plant died $; \mathrm{SN}=$ systemic necrosis; $\mathrm{SI}=$ symptomless infection; $\mathrm{VN}=$ vein necrosis.

${ }^{\mathrm{b}}$ No reaction and negative result in direct antigen coated-enzyme-linked immunosorbent assay (DAC-ELISA) using Peanut stripe virus (PStV) antiserum. The virus was presumed to be closely related to PStV during initial serological tests, hence PStV antiserum was used to verify virus infection during host range studies.

${ }^{c}$ Arachis sp. used as ornamental plant in Recife, State of Pernambuco.

${ }^{\mathrm{d}}$ Wild Arachis sp. naturally occurring in the state of Paraíba.

Table 2. Seed and aphid transmission of a peanut isolate of Cowpea aphid-borne mosaic virus

\begin{tabular}{llcc}
\hline Transmission by & Test plant $^{\mathbf{a}}$ & Number of plants $^{\mathbf{b}}$ & Percent transmission $^{\text {Seed }}$ \\
\hline \multirow{2}{*}{ Aphid } & Peanut & $1 / 610$ & 0.2 \\
Aphis gossypii & Cowpea & $47 / 796$ & 5.9 \\
& & & \\
\multirow{2}{*}{ Toxoptera citricidus } & Peanut & $23 / 26$ & 88.5 \\
& Cowpea & $12 / 28$ & 42.9 \\
& Peanut & $15 / 18$ & 83.3 \\
& Cowpea & $9 / 22$ & 40.9 \\
\hline
\end{tabular}

a Cultivars used: peanut, BR-1; cowpea, Sempre Verde; and soybean, Doko.

${ }^{\mathrm{b}}$ Number infected over number tested and confirmed by direct antigen coated-enzyme-linked immunosorbent assay (DAC-ELISA) using Peanut stripe virus (PStV) antiserum. The virus was presumed to be closely related to PStV during initial serological tests and hence PStV antiserum was used to verify virus infection during seed and aphid transmission studies.

${ }^{c}$ Source was peanut (cv. BR-1) inoculated with a single lesion virus isolate. field of 1 to 2 ha. Two fields had symptomatic plants by the end of the 1995 growing season: a 2.5 -ha field intercropped with cowpea showed 20 and $60 \%$ infected peanut and cowpea plants, respectively. In 1997, a 1.5-ha irrigated peanut field next to a large cowpea field with infected plants exhibited a gradient in which 10 to $15 \%$ of peanut plants closest to the cowpea were infected. Of all the samples collected from several intercropped legumes, only cowpea samples reacted with PStV antiserum and induced the typical symptoms of ring spots and blotches when mechanically transmitted to peanut (cv. BR-1). The virus was presumed to be closely related to PStV during initial serological tests, and hence PStV antiserum was used to verify virus infection during host range studies. No symptomatic peanut plants were observed in surveys conducted in Pernambuco, Bahia, and São Paulo (Fig. 1).

Host range. A single lesion isolate was used for host range studies, and the results are presented in Table 1. Systemic infection was observed in Nicotiana benthamiana Domin. and in some cultivars of peanut, cowpea, and soybean. All of the six peanut cultivars showed blotches and chlorotic ring spots. In addition, four cultivars exhibited leaf distortion. The cultivar Florunner also showed some mottling (Table 1). The wild Arachis species was found to be systemically infected. Cowpea cv. TVu 3433 exhibited both localized and systemic infection, leading to plant death (Table 1).

Serology and transmission. In DACELISA, the virus reacted consistently with PStV and PeMoV and weakly with BCMV and SbMV antisera, while no reaction was observed with MDMV, PSbMV, and SCMV antisera. The virus was readily transmitted by $T$. citricidus and A. gossypii from peanut to peanut and to cowpea (Table 2). The transmission rates to peanut were higher than those to cowpea by both the aphid species (Table 2). Growout tests showed some seedlings developing symptoms similar to those observed in the field (Table 2). All the germinated seedlings were tested for the presence of the virus by ELISA, and only those that showed typical symptoms contained the virus.

Amplification and sequence analyses of the CP gene. Genomic amplification from a purified virus preparation resulted in a PCR product of approximately $1.2 \mathrm{~kb}$. Sequence analysis confirmed that the product encoded a polypeptide of 356 amino acids and contained a 3'-UTR of 228 nucleotides (Fig. 2). On the basis of sequence relationships with known potyviruses, the first 80 amino acids in the polypeptide were presumed to represent the $N I b$ gene product. Assuming a cleavage site between the $N I b$ and $\mathrm{CP}$ between the glutamine (Q80) and serine (S81), the CP was found to be 276 amino acids in length (Fig. 2). Sequence comparisons indicated a 
$\begin{array}{lllllll}V & V & V & V & V & v & v\end{array}$ ATGATCGAGGCGTGGGGATATCCCGAACTGTTGCAAGAGATTAGAAAATTCTATCTTTGGTTATTGCAAA $\begin{array}{llllllllllllllllllllllllll}\mathrm{M} & \mathrm{I} & \mathrm{E} & \mathrm{A} & \mathrm{W} & \mathrm{G} & \mathrm{Y} & \mathrm{P} & \mathrm{E} & \mathrm{L} & \mathrm{L} & \mathrm{Q} & \mathrm{E} & \mathrm{I} & \mathrm{R} & \mathrm{K} & \mathrm{F} & \mathrm{Y} & \mathrm{L} & \mathrm{W} & \mathrm{L} & \mathrm{L} & \mathrm{Q} & \mathrm{R}\end{array}$ GGGATGAATTTAAGGAGTTGGCTAGTCTTGGGAAAGCTCCTTACATTGCAGAAACTGCTCTTAAAAAGCT $\begin{array}{llllllllllllllllllllllll}D & E & F & K & E & L & A & S & L & G & K & A & P & Y & I & A & E & T & A & \text { L } & K & K & I\end{array}$ CTACACTGATGAGCAGGCCTCAGAGAAAGAATTGCAGAGGTATCTTCAAGATATCCTTTCCTTTTATGAC $\begin{array}{llllllllllllllllllllllll}Y & T & D & E & Q & A & S & E & K & E & L & Q & R & Y & L & Q & D & I & L & S & F & Y & D\end{array}$ GACTGCGAACTAGAAGATGTTGTGCTCCAATCTGGTGAAAGGCAAAAAGAAGAATTGGATGCAGGCAAGG

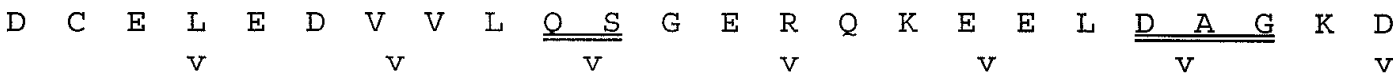
ACAAAGACAAGGATAAAGGAACCAAAGAGCAGTCCACACAACAGAAGCAAGCAAGGAACAAAGGAGTCAC

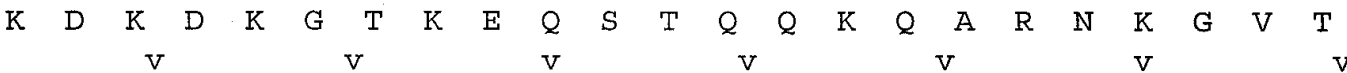
GGAAACGGAGAGGGACGTTGCAAATAGCTCTTCAGGGCAATTGGTTCCACGTTTACAAAAGATCAGTAAA

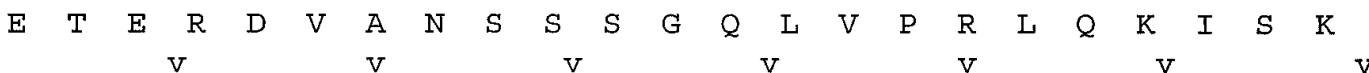
AAGATGAATCTCCCCGTGATTGCTGGCAGAGTTATTCTCAATTTGGACCACCTGATAGAATATAAGCCAG $\begin{array}{llllllllllllllllllllllll}K & M & N & I & P & V & I & A & G & R & V & I & L & N & L & D & H & I & I & E & Y & K & P & A\end{array}$ CGCAAATTGACCTGTACAACACCAGGGCATCAAAGACACAGCTCAGTAAATGGTTTGAGGCCATTAAAGA

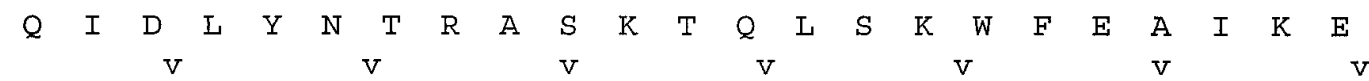
GGAGTACGAGCTGGATGATGACAAGATGGGTGTTATAATGAATGGTTTCATGGTTTGGTGCATCGAGAAT

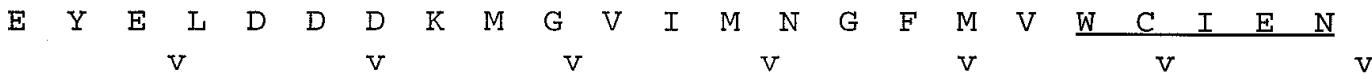
GGAACTTCACCTGACATAAATGGAGTGTGGACCATGATGGATGGAGATGAGCAAGTGGAATTTCCGCTCA

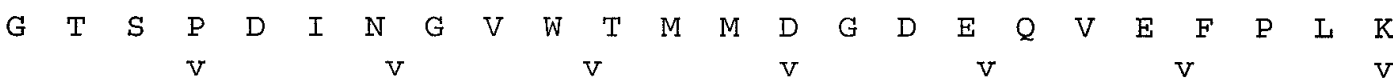
AACCCATTGTAGAAAATGCAAAACCCACACTTAGACAAATTATGCACCACTTCTCAGACGCAGCTGAAGC

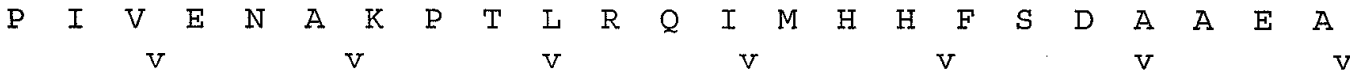
GTACATTGAGATGAGAAATTCTGAAGGGTTCTACATGCCCAGGTATGGACTACTGAGGAATTTAAGAGAT

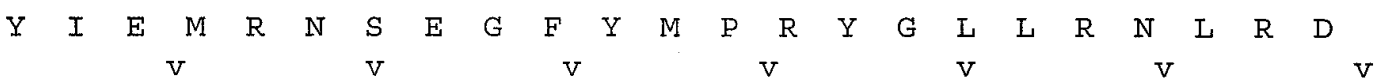
AAGAGCTTGGGAAGGTATGCTTTCGATTTCTATGAAGTCACATCTAAGACTTCCGAAAGAGCAAGGGAAG $\begin{array}{llllllllllllllllllllllll}K & S & L & A & R & Y & A & F & D & F & Y & E & V & T & S & K & T & S & E & R & A & R & E & A\end{array}$ CAATAGCGCAAATGAAGGCTGCAGCTCTCGCCAACGTTAACACCAGGATGTTTGGCCTGGATGGGAACGT

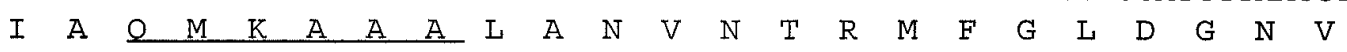
GGCAACAACTAGTGAGAACACTGAGAGGCACACTGCCGCTGATGTGAATCAGAACATGCACTCCCTCTTG

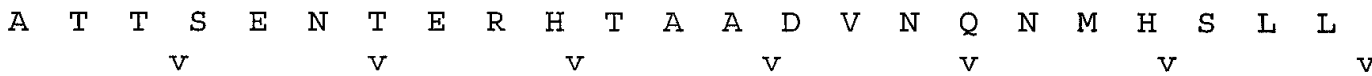
GGAATGACGCATGGGCAGTAAAGGCTTGGGTTCTGCCCTCGCCACAGTTATCGTCTCATGACCCTAGCTA G $\quad M \quad T \quad H \quad G \quad Q<356$ $\begin{array}{lllllll}V & v & v & v & V & V & v\end{array}$ ATGGTTGGTTTTAGTAAATAGTACGCATATATCCAGTCGAACTATATATGTTAGTGTGGTCTTCCACCAG $\begin{array}{cccccc}v & v & v & v & v & v \\ \text { TATGTTATGTTACTTTAATTGAACTTAGCGGAGAGGCCATACCCCGGTTGGAGTGCTCAGAGTGACTGTG }\end{array}$ $\mathrm{V} \quad \mathrm{V}$ TCACGTGTAGTAACCGAGATTTGGTATGAAAACTCTCC 1299

Fig. 2. Nucleotide and deduced amino acid sequence of the $3^{\prime}$ terminal region (excluding the poly A tail) of the potyvirus from Brazil. Amino acid sequences conserved in most potyviruses are underlined. The putative proteolytic cleavage site between $N I b$ and coat protein $(\mathrm{Q} / \mathrm{S})$ and the DAG motif potentially associated with the aphid transmission are double underlined. 
(A)

BZ9
SAPV
CABMV-Z
CABMV-GA

BZ9

SAPV

CABMV-Z

CABMV-GA

BZ9

SAPV

CABMV - Z

CABMV-GA

BZ9

SAPV

CABMV-Z

CABMV-GA

BZ9

SAPV

CABMV - $Z$

CABMV-GA

(B)

BZ9

SAPV

CABMV - Z

CABMV-GA

BZ9

SAPV

CABMV - Z

CABMV-GA

BZ9

SAPV

CABMV - Z

CABMV-GA

BZ9

SAPV

CABMV-Z

CABMV-GA
SGERQKEELDAGKDKDKDKGTKEQSTQQKQARNKGVTETERDVANSSSGQLVPRLQKISK SGRKQEE-LDAGKDKEKTKEGEEQSTQQKQTKDKGTKETERDVATS SSGQLVPRLQKIGK SDERQKE - LDAGKDKDKAKEAREQSTQQKQAKNKGAKETERDVAASSSGQLVPRLQKISK SDERQKE-LDAGKEKDKAKEAKEQSTQQKQAKNKGAKETERDVAASSSGQLVPRIQKISK $* \quad . * * * * * * . * * * \quad * * * * * * * * \ldots * * \quad * * * * * * * * * * * * * * * * * * * * *$

KMNLPVIAGRVILNLDHLIEYKPAQIDLYNTRASKTQLSKWFEAIKEEYELDDDKMGVIM KMNLPMVAGKVILDLTHLIEYKPAQIDLYNTRASKTQFNKWFEAIKEEYELDDDKMGVIM KMNLPMVAGRLILNIDHLIEYKPKQIDLYNTRASKAQFNTWFEAVKEEYELDDDKMSVIM KMINLPMVAGRLILNIDHLIEYKPKQIDLYNTRASKAQFNTWFEAVKEEYELDDDKMSVIM $* * * * * \ldots * * \ldots * \ldots * * * * * * * * * * * * * * * * * * . * \quad * * * * . * * * * * * * * * * * * * *$

NGFMVWCIENGTSPDINGVWTMMDGDEQVEFPLKPIVENAKPTLRQIMHHFSDAAEAYIE NGFMVWCIENGTSPDVNGVWTMMDGDEQVEFPLKPIVENAKPTLRQIMHHFSDAAEAYIE NGFMVWCIENGTSPDVNGVWTMMDGDEQVEFPLKPIVENAKPTLRQVMHHFSDAAEAYIE NGFMVWCIENGTSPDVNGVWTMMDGDEQVEFPLKP IVENAKPTLRQVMHHFSDAAEAYIE

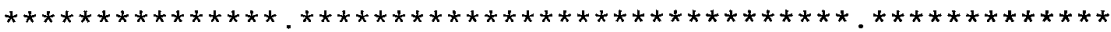

MRNSEGFYMPRYGLLRNLRDKSLARYAFDFYEVTSKTSERAREAIAQMKAAALANVNTRM MRNSEGFYMPRYGLLRNLRDKSLAARYAFDFYEVTSKTPDRAREAIAQMKAARLANVNTRM MRNSEGFYMPRYGPLRNLRDKSLARYAFDFYEVTSKTSDRAREAIAQMKAAALANVNTRM MRNSEGFYMPRYGLLRNLRDKSLARYAFDFYEVTSKTSDRAREAIAQMKAAALANVNTRM $* * * * * * * * * * * * * \quad * * * * * * * * * * * * * * * * * * * * * * * . * * * * * * * * * * * * * * * * * * * *$

FGLDGNVATTSENTERHTAADVNQNMHSLLGMTHGQ FGLDGNVATTSENTERHTATDVNQNMHSLLGMTHGQ FGLDGNVATVSENTERHTAADVNQNMHSLLGMTHGQ FGLDGNVATISENTERHTAADVNQNMHSLLGMTHGQ $* * * * * * * * * * * * * * * * * *, * * * * * * * * * * * * * * * *$

AGGCTTGGGTTCTGCCCTCGCCACAGTTATCGTCTCATGACCCTAGCTAATGGTTG AGGTTTGGGTTCCGCCCTCACCACAGTTATCGTCTCACGAACTTAGCTAATGGTTG AGGCTTGGGTTCCGCCCTCGCCACAGTTATCGTCTCATGACCTTAGCTAATGGTTG AGGCTTGGGTTCCGCCCTCGCCACAGTTATCGTCTCATGACCTTAGCTAATGGTTG $\star * * * * * * * * * * * * * * * * * * * * * * * * * * * * * * * * * * * * * * * * * * * * * * * * * *$

GTTTTAGTAAATAGTACGCATATATCCAGTCGAACTATATATGTTAGTGTGG-TCTTCCA GTTTTAGTAGATAGTACGCATATATCCAGTTAAACTATATATGTTAGTGTGGGTCACCCA GTTTTAGTAAATAGTACGCATATATCCAGTCGAACTATATATGTTAGTGTGG-TTTTCCA GTTTTAGTAAATAGTACGCATATATCCAGTCGAACTATATATGTTAGCGTGG-TCTTCCA $* * * * * * * * * * * * * * * * * * * * * * * * * * * * * \quad * * * * * * * * * * * * * * * * * * * * * * * *$

CCAGT-ATGTTATGTTACTTTAATTGAACTTAGCGGAGAGGCCATACCCCGGTTGGAGTG CCGGTTGCGTTATGTTACTTTAATTGAACTTAGCGGAGAGGCCATACCCCGATCGGAGTG CCAGT-ATGTTATGTTACTTTAATTGAACTTAGCGGAGAGGCCATACCCCGGTTGGAGTG CCAGT-ATGTTATGTTACTTTAATTGAACTTAGCGGAGAGGCCATACCCCGGTTGGAGTG $* * * * \quad * * * * * * * * * * * * * * * * * * * * * * * * * * * * * * * * * * * * * * * * * * * * * * * *$

CTCAGAGTGACTGTGTCACGTGTAGTAACCGAGATTTGTGTATGAAAACTCTCC CTCAGAGTGGTTTTACCATG-GTAGTCATCGAGATTGG- -TATGAAAACTCTCT CTCAGGGTGACCGTGTCACGCGTAGCTACCGAGATTTGTGTATGAAAACTCTCT CTCAGGGTGACTGTGTCACGCGTAGCTACCGAGATTTGTGTATGAAAACTCTCT $* * * * * * * \quad * \quad * * * * * * * \quad * * * * * * * * * * * * * * * * * * * * * *$

Fig. 3. Multiple alignment of (A) coat protein (CP) sequences and (B) $3^{\prime}$ untranslated regions (UTR) of the potyvirus from Brazil with available Cowpea aphid-borne mosaic virus (CABMV) sequences. CABMV-GA, from Georgia, USA (13,21); CABMV-Z, from Zimbabwe (20); SAPV/CABMV-SA, South African passiflora potyvirus, now classified as a South African strain of CABMV (4,11). Asterisk indicates identical amino acid at a given position, and a period indicates chemically similar amino acid residue in (A). Asterisk indicates identical nucleotide at a given position in (B). A dash indicates a gap. Alignments were generated using CLUSTALW (25). 
high degree of homology between this virus and the other viruses of the passionfruit woodiness virus group. In particular, this virus was found to be most closely related to CABMV and its isolates reported from Zimbabwe (CABMV-Z) and Georgia (CABMV-GA) and South African passiflora virus (SAPV) (Fig. 3A and B). Phylogenetic analysis based on $\mathrm{CP}$ sequence grouped this virus with the CABMV isolates and confirmed the relationship with CABMV (Fig. 4). Similar phylogenetic relationships were seen when the 3'-UTRs were compared (not shown).

\section{DISCUSSION}

The serological, biological, and molecular properties of a peanut-infecting isolate of CABMV from Brazil are presented in this paper. ELISAs using antisera specific to selected peanut-infecting viruses indicated that it was a potyvirus. The susceptibility of cowpea cv. Tvu 3433 suggested that the virus could be CABMV. The molecular data on the sequence of the
$\mathrm{CP}$ gene and 3'-UTR provided unequivocal evidence that the virus was a strain of CABMV. Based on this finding, current surveys for peanut viruses in the region include a panel of CABMV-specific monoclonal and polyclonal antibodies. The peanut isolate of CABMV has been found annually in peanut fields in both monocropping and intercropping with cowpea systems, and it was not found in other peanut-producing areas of Brazil. The peanut seed used in the four fields where the infected plants were found in 1995 originated from São Paulo, a region that was free of both the virus and cowpea. This suggests the transfer and adaptation of CABMV from cowpea to peanut occurred in the Paraíba region, where intercropping of peanut and cowpea is common.

Although the seed transmission observed in peanut $\mathrm{cv}$. BR-1 under experimental conditions was very low, the relatively high aphid transmission from peanut to peanut becomes significant should this virus be introduced to a new location, po-

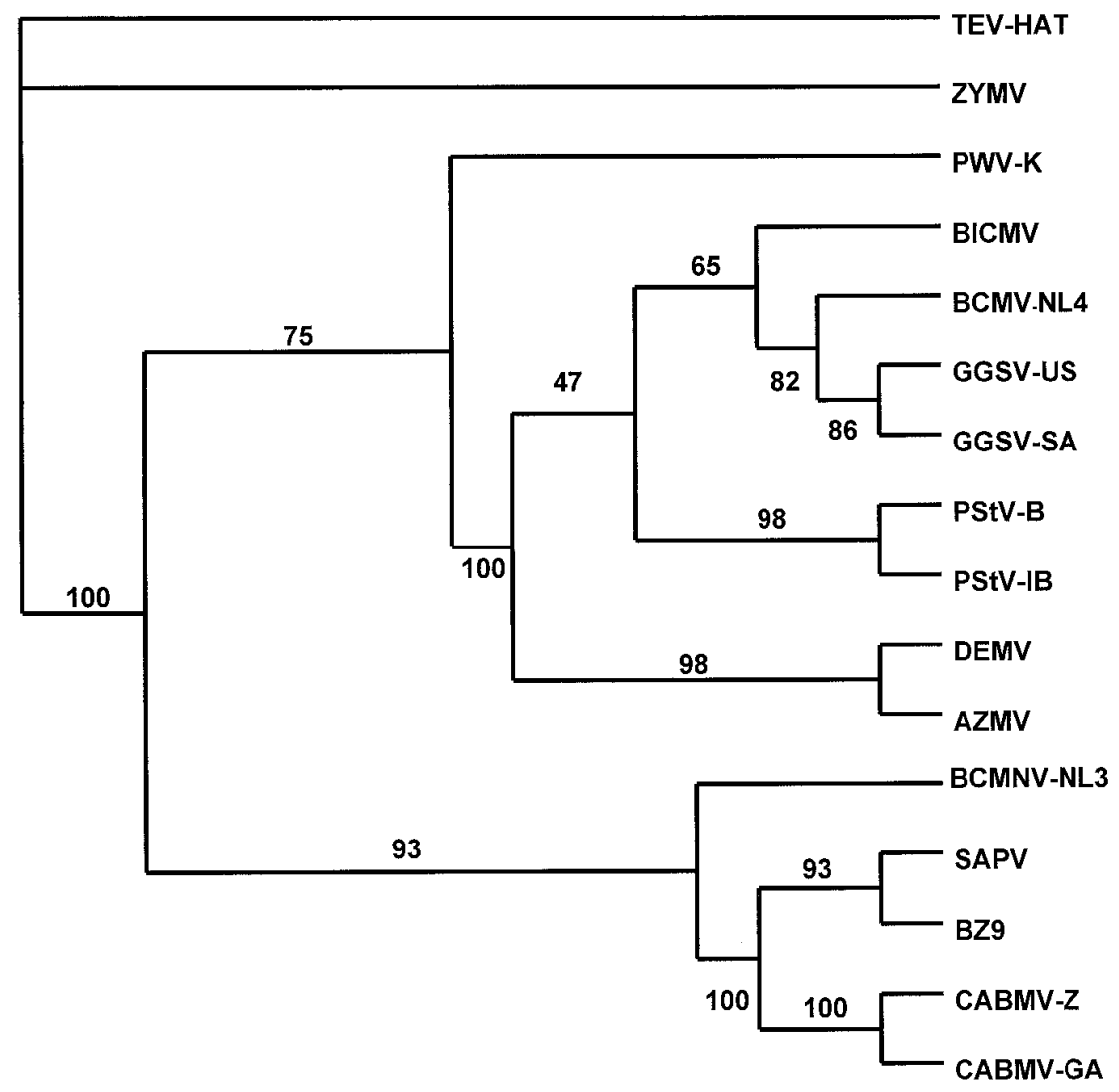

Fig. 4. Phylogenetic tree derived from coat protein sequences of potyvirus from Brazil and selected potyviruses. Percent reliability value given above each branch indicates how often corresponding cluster was found among the 1,000 intermediate trees. Vertical length of branches was arbitrary. AZMV, Azuki bean mosaic virus; BCMV-NL4, Bean common mosaic virus, strain NL4; BCMNVNL3, Bean common mosaic necrosis virus, strain NL3; BZ9, peanut-infecting potyvirus from Brazil (this study); BlCMV, Black eye cowpea mosaic virus; CABMV-Z, Cowpea aphid-borne mosaic virus isolate from Zimbabwe; CABMV-GA, CABMV isolate from Georgia. GGSV-US, gaur green sterile virus, US isolate; GGSV-SA, South African isolate of GGSV; PStV-B, Peanut stripe virus, blotch isolate; PStV-IB, Indonesian blotch isolate of PStV; DEMV, Dendrobium mosaic virus; PWV-K, Passionfruit woodiness virus, strain K; SAPV, South African passiflora potyvirus, now classified as South African strain of CABMV; TEV, Tobacco etch virus, HAT strain; ZYMV, Zucchini yellow mosaic virus. tentially leading to an outbreak. The fact that all six peanut cultivars tested showed systemic infection and a locally occurring wild peanut showed susceptibility under experimental conditions emphasizes the necessity for developing sensitive, specific, and rapid detection assays such as PCR and possibly a multiplex RT-PCR for detection of this and other seed-borne peanut viruses.

\section{ACKNOWLEDGMENTS}

Financial support from the American Peanut Foundation and the Georgia Agricultural Commodity Commission for Peanut is gratefully acknowledged. The surveys were supported by the CNPA-EMBRAPA x UFRPE agreement and by the IAC, Campinas, SP, Brazil. Access to sequence analysis software and GenBank was provided by the Research Computing Resource, University of Georgia. S. S. Pappu is supported by a postdoctoral fellowship from the College of Agricultural and Environmental Sciences, University of Georgia.

\section{LITERATURE CITED}

1. Altschul, S. F., Gish, W., Miller, W., Myers, E. W., and Lipman, D. J. 1990. Basic local alignment search tool. J. Mol. Biol. 215:403410.

2. Benson, D. A., Boguski, M. S., Lipman, D. J., Ostell, J., Ouellette, B. F., Rapp, B. A., and Wheeler, D. L. 1999. GenBank. Nucleic Acids Res. 27:12-17.

3. Bharathan, N., Reddy, D. V. R., Rajeshwari, R., Murthy, V. K., Rao, V. R., and Lister, R. M. 1984. Screening peanut germ plasm lines by enzyme-linked immunosorbent assay for seed transmission of peanut mottle virus. Plant Dis. 68:757-758.

4. Brand, R. J., Burger, J. T., and Rybicki, E. P. 1993. Cloning, sequencing and expression in Escherichia coli of the coat protein gene of a new potyvirus infecting South African Passiflora. Arch. Virol. 128:29-41.

5. Demski, J. W., and Reddy, D. V. R. 1997 Diseases caused by viruses. Pages 53-59 in: Compendium of Peanut Diseases. N. K. Burella, D. M. Porter, R. Rodriguez-Kabana, D. H. Smith, and P. Subrahmanyam, eds. American Phytopathological Society, St. Paul, MN.

6. Demski, J. W., Reddy, D. V. R., Sowell, G. Jr., and Bays, D. 1984. Peanut stripe virus - a new seed-borne potyvirus from China infecting groundnut. Ann. Appl. Biol. 105:495-501.

7. Demski, J. W., and Warwick, D. 1986. Testing peanut seeds for peanut stripe virus. Peanut Sci. 13:38-40.

8. Devereux, J., Haeberli, P., and Smithies, O. 1984. A comprehensive set of sequence analysis programs for the VAX. Nucleic Acids Res. 12:387-395.

9. Hobbs, H. A., Reddy, D. V. R., Rajeshwari, R., and Reddy, A. S. 1987. Use of direct antigen coating and protein A coating ELISA procedures for detection of three peanut viruses. Plant Dis. 71:747-749.

10. Jain, R. K., Pappu, S. S., Pappu, H. R., Culbreath, A. K., and Todd, J. W. 1998. Molecular diagnosis of tomato spotted wilt tospovirus infection of peanut and other field and greenhouse crops. Plant Dis. 82:900-904.

11. McKern, N. M., Strike, P. M., Barnett, O. W., Dijkstra, J., Shukla, D. D., and Ward, C. W. 1994. Cowpea aphid-borne mosaic virus-Morocco and South African Passiflora virus are strains of the same potyvirus. Arch. Virol. 136:207-217.

12. Page, R. D. M. 1996. TreeView: An application to display phylogenetic trees on personal computers. Comp. Appl. Biosci. 12:357-358. 
13. Pappu, H. R., Pappu, S. S., and Sreenivasulu, P. 1997. Molecular characterization and interviral homologies of a potyvirus infecting sesame (Sesamum indicum) in Georgia. Arch. Virol. 142:1919-1927.

14. Pappu, S. S., Brand, R., Pappu, H. R., Rybicki, E. P., Gough, K. H., Frenkel, M. J., and Niblett, C. L. 1993. A polymerase chain reaction method adapted for selective amplification and cloning of $3^{\prime}$ sequences of potyviral genomes: Application to dasheen mosaic virus. J. Virol. Methods 41:9-20.

15. Pappu, S. S., Pappu, H. R., Rybicki, E. P., and Niblett, C. L. 1994. Unusual amino terminal sequence characterizes the coat protein of dasheen mosaic potyvirus. J. Gen. Virol. 75:239-242.

16. Pio-Ribeiro, G., Pappu, S. S., Rappu, H. R., Reddy, D. V. R., and Andrade, G. P. 1998. Biological, serological, and molecular characterization of a potyvirus seed-borne in peanut in Brazil. Phytopathology 88:S71.

17. Reddy, D. V. R. 1991. Groundnut viruses and virus diseases: Distribution, identification and control. Rev. Plant Pathol. 70:665-678.

18. Rhoads, D. D., and Roufa, D. S. 1985. Emetine resistance of Chinese hamster cells: Structure of wild type and mutant ribosomal protein S14 messenger RNA species. Mol. Cell. Biol. 5:1655-1659.

19. Sambrook, J., Fritsch, E. F., and Maniatis, T. 1989. Molecular Cloning: A Laboratory Manual. Cold Spring Harbor Laboratory, Cold Spring Harbor, NY

20. Sithole-Niang, I., Nyathi, T., Maxwell, D. P., and Candresse, T. 1996. Sequence of the 3'terminal region of a Zimbabwe isolate of cowpea aphid-borne mosaic virus (CABMV). Arch. Virol. 141:935-943.

21. Sreenivasulu, P., Demski, J. W., Purcifull, D. E., Christie, R. G., and Lovell, G. R. 1994. A potyvirus causing mosaic disease of sesame
(Sesamum indicum). Plant Dis. 78:95-99.

22. Sreenivasulu, P., Kuhn, C. W., Naidu, R. A. Demski, J. W., Reddy, D. V. R., and Nayudu, M. V. 1991. Viruses infecting peanuts (Arachis hypogaea): Taxonomy, identification, and disease management. Ga. Agric Exp. Stn. Res. Bull. 406.

23. Strimmer, K., and von Haeseler, A. 1997. Quartet puzzling: A quartet maximum likelihood method for reconstructing tree topologies. Mol. Biol. Evol. 13:964-969.

24. Swafford, D. L. 1998. PAUP*. Phylogenetic Analysis Using Parsimony (*and other methods). Version 4.0. Sinauer Associates, Sunderland, MA.

25. Thompson, J. D., Higgins, D. G., and Gibson, T. J. 1994. CLUSTAL W: Improving the sensitivity of progressive multiple sequence alignment through sequence weighting, positions-specific gap penalties and weight matrix choice. Nucleic Acids Res. 22:4673-4680. 